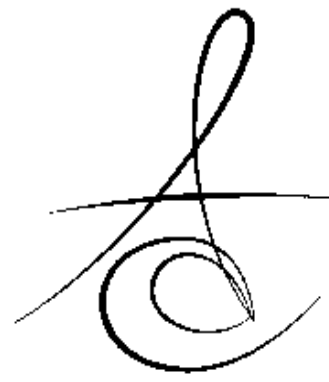

Makale Kodu/Article code: 1601

Makale Gönderilme tarihi: 31.03.2014

Kabul Tarihi: 05.05..2014

\section{DENTÍN AŞIRI HASSASİYETİ: TANI VE TEDAVİ YÖNTEMLERİ}

\section{DENTIN HYPERSENSITIVITY: DIAGNOSIS AND TREATMENT METHODS}

Dt. İzgen HACIOĞULLARI*

Prof. Dr. Nuran ULUSOY*

Dr. Dt. Faruk $E R^{*}$

\section{ÖZET}

Dentin aşırı hassasiyeti, açığa çıkmış dentinin termal, buharlaşma, dokunma, elektriksel, kimyasal veya osmotik uyaranlara karşı cevap olarak oluşturduğu kısa süreli, keskin ve şiddetli ağrı olarak tanımlanmaktadır. Ağrı mekanizması ile ilgili çeşitli teoriler ortaya atılmış ancak; dentin aşırı hassasiyetinin oluşturduğu ağrı mekanizması halen kesin olarak anlaşılamamıştır. Epidemiyolojik çalışmalar da çok farklı sonuçlar elde edilmiştir. Etyolojisi multifaktöriyeldir. Görülme sıklığı gün geçtikçe artan dentin aşırı hassasiyeti diğer tüm patolojilerin elenmesi ile teşhis edilebildiği için teşhisi zor bir durumdur. Tedavisi amacıyla pek çok materyal ve yöntem denenmiştir ancak henüz altın standart olabilecek bir yöntem belirlenememiştir. Bu derlemede dentin aşırı hassasiyetinin tanımı, ağrı mekanizması ile ilgili teoriler, etiyoloji ve risk faktörleri, tanı ve teşhisi ile tedavide kullanılan materyal ve yöntemler tartışılacaktır.

Anahtar Kelimeler: Ağrı Mekanizması, Dentin Aşırı Hassasiyeti, Etiyoloji, Tedavi

\section{GİRİŞ}

Dentin aşırı hassasiyeti (DAH), açığa çıkmış dentinin, termal, buharlaşma, dokunma, elektriksel, osmotik veya kimyasal uyaranlara karşı oluşturduğu ve başka hiçbir dental patoloji, defekt ve hastalık olarak tanısı konulamayan, tipik, kısa süreli, şiddetli, keskin ağrı ile karakterize durumudur. ${ }^{1}$

Bu durumu açıklamak için kullanılmış terimler arasında; dentin hassasiyeti/ dentin aşırı hassasiyeti (hipersensitivitesi),dentinal aşırı hassasiyet, servikal hassasiyet/ servikal aşırı hassasiyet, kök hasassiyeti/

\section{ABSTRACT}

Dentin hypersensitivity has been defined as the short, sharp and severe pain arising from exposed dentin in response to thermal, evaporative, tactile, electrical, chemical or osmotic stimuli. Various theories about pain mechanism of dentin hypersensitivity have been reported but none of the pain mechanisms has not been proved yet. The epidemiological research reported various prevelances about dentin hypersensitivity and day after day it is increasing. The aetiology of dentin hypersensitivity is multifactorial. Diagnosis is difficult. Different materials and methods have been used for the treatment of dentin hypersensitivity but a gold standart for treatment has not been found yet. The definition, theories about pain mechanisms, aetiology and risk factors, diagnosis and treatment of dentin hypersensitivity will be discussed in this review.

Keywords: Pain Mechanism, Dentin Hypersensitivity, Aetiology, Treatment

kök aşırı hassasiyeti, sement hassasiyeti/sement aşırı hassasiyeti sayılabilir. ${ }^{2}$

DAH ile ilgili günümüze dek yapılan prevelans çalışmaları \%1.34'den \%98'e varan farklı sonuçlar ortaya koymuştur. ${ }^{3,4}$ Etnik köken, sosyoekonomik durum, çalışmanın yapıldığı bölgenin konumu, kültürel yapı gibi özelliklerinin farklılık gösterdiği, hedef olarak seçilen populasyondaki farklar; beslenme alışkanlıkları, oral hijyen alışkanlıkları, ağız hastalıklarına karşı tutum, psikolojik, durumsal ve duygusal faktörler gibi hastaya ait bireysel parametrelerin varlığı ve ağrı bildirimlerinin subjektif oluşu; çalışmalarda kullanılan araştırma, muayene ve teşhis yöntemlerinin farklılı̆ı

\footnotetext{
* Yakın Doğu Üniversitesi Diş Hekimliği Fakültesi Restoratif Diş Tedavisi Anabilim Dalı
} 
araştırmayı yöneten ve klinik değerlendirmeyi yapan kaynaklardaki farklılıklar, klinik araştırmaların subjektif oluşu ve farklı uyaranlara karşı muayene edilen hastaların bireysel reaksiyonlarına bağlı oluşu, hasta ve hekim arasında Hawthorne, placebo ve nocebo gibi etkilerin varlığı gibi nedenler hem epidemiyolojik çalışmalar hem de tedavi yöntemleri ile ilgili çalışmalardaki büyük farklara sebep olarak düşünülmektedir. 1,5-12

Dişlerde DAH'nin gelişebilmesi için dişin dentin yüzeyinin açığa çıkması (lezyon lokalizasyonu) ve birbirine yakın dentin tübüllerinin açı̆̆a çıkması (lezyonun başlaması/inisiasyonu) gerekmektedir. ${ }^{13}$ DAH'nin etiyolojsinde rol oynayan birçok faktör ve risk faktörleri mevcuttur (Tablo 1). ${ }^{13,15-17}$

Tablo 1. DAH etiyoloji ve risk faktörleri

1.Çürük olmayan servikal lezyonlar (Abrazyon, Atrizyon, Abfraksiyon, Erozyon)

2. \%10 görülme sıklığına sahip, dentini kole bölgesinde açıkta bırakacak şekilde mine-sement birleşiminin olmadığı durumlar

3. Diş yüzeylerindeki 10-15 $\mu \mathrm{m}$ kalınlığa sahip smear tabakasının, asidik yiyecek ve içecekler, alkollü içecekler, bazı bitkisel çaylar, bazı gargaralar ve deterjan olarak sodyum lauril sülfat içeren diş macunları tarafından uzaklaştırılması

4. Yumuşak dokuların hareketi, periodontal hastalıkların varlığı: İnce alveoler kemik, periodontitis ve bunun cerrahi ve cerrahi olmayan tedavileri, alveoler kemiğin bukkal ve lingual dehisens ve fenestrasyonları, travma, ortodontik tedavi, oral piercing, kendi kendini yaralama, diş eti biyotipi, keratinize gingivayı travmatize eden prostodontik tedaviler, frontolateral bruksizm, yetersiz oral hijyen veya travmatik diş fırçalama gibi nedenlerle gelişen diş eti çekilmeleri

5. Vital diş beyazlatma işlemleri sonrasında çoğu kişide hassasiyet gelişmekte ve yaklaşık 1-4 gün içerisinde sona ermektedir ancak; öncesinde hassasiyet şikayeti olan bireylerde beyazlatma işleminin DAH şiddetini artırmaktadır

6.Tükürüğün tamponlama yeteneği ve akış hızı, asitlerin ağız içinde dağılımı ve kalma süresi, dişin yapısı ve remineralizasyon potansiyeli, pellikıl kalınlığı ve yükü

7.Parafonksiyonel alışkanlıklar

8.Diş fırçalama şekli ve sıklığı (Özellikle diş fırçalama döngüsü önemlidir. İlk fırçalanmaya başlanan bölgelere, fırçalamanın sonuna doğru ulaşılan bölgelere oranla daha fazla zaman harcandığı ayrıca diş macunun bu bölgelere temasının da daha fazla olduğu gösterilmiştir.

9.Kullanılan ağız hijyen ürünleri

10.Sistemik rahatsızlıklar

11.Mesleki faktörler

Ağrı, gerçek veya potansiyel hasar sonucu oluşan, hoşnutsuzluk veren duyusal, duygusal deneyim olarak tanımlanmıştır. DAH'de ağrı uygun koşulların devamlılığı durumunda klasik olarak keskin, kısa ve ani nöbetlerle karakterizedir. DAH ile ilgili güncel fikirlerin çoğu bilimsel kanıtlardan çok mantığa yatkın ve makul varsayımlardan ibarettir (Tablo 2). ${ }^{13,14,18}$
Tablo 2. DAH ağrı mekanizmaları.

\begin{tabular}{|c|c|c|c|}
\hline Teori & $\begin{array}{c}\text { Doğrudan } \\
\text { Sinir } \\
\text { Sonlanması } \\
\text { Teorisi }\end{array}$ & $\begin{array}{c}\text { Dentinal } \\
\text { Reseptör } \\
\text { Mekanizması } \\
\text { (Odontoblast } \\
\text { Reseptör) } \\
\text { Teorisi }\end{array}$ & Hidrodinamik Teori \\
\hline Açıklama & $\begin{array}{l}\text { Dentin serbest } \\
\text { duyu sinir } \\
\text { sonlanmaları ile } \\
\text { innerve } \\
\text { edilmekte ve } \\
\text { böylelikle } \\
\text { uyaran ile sinir } \\
\text { direkt olarak } \\
\text { tetiklenmektedi } \\
\text { r. Uyarının } \\
\text { dentin tübülleri } \\
\text { içerisinde } \\
\text { bulunan } \\
\text { Schwann kilfı } \\
\text { taşımayan } \\
\text { miyelinsiz } \\
\text { duyusal sinir } \\
\text { liflerinin } \\
\text { doğrudan } \\
\text { uyarıması } \\
\text { sonucu } \\
\text { olusstuğu } \\
\text { düşünülmekted } \\
\text { ir. }\end{array}$ & $\begin{array}{l}\text { Odontoblastlar } \\
\text { kimyasal veya } \\
\text { mekanik } \\
\text { uyaranlara karşı } \\
\text { nörotransmitterle } \\
\text { r salgılamakta ve } \\
\text { pulpal sinirlerle } \\
\text { yaptıkları } \\
\text { sinaptik kavşak } \\
\text { aracilığı ile } \\
\text { membran } \\
\text { potansiyel } \\
\text { değişikliklerini } \\
\text { dengeleyecek } \\
\text { reseptör hücreler } \\
\text { gibi } \\
\text { davranmaktadır. } \\
\text { Bu pulpodentinal } \\
\text { birleşimde yer } \\
\text { alan sinir } \\
\text { sonlanmaları } \\
\text { aracilığı ile } \\
\text { ağrının } \\
\text { algılanmasına } \\
\text { neden olabilir. }\end{array}$ & 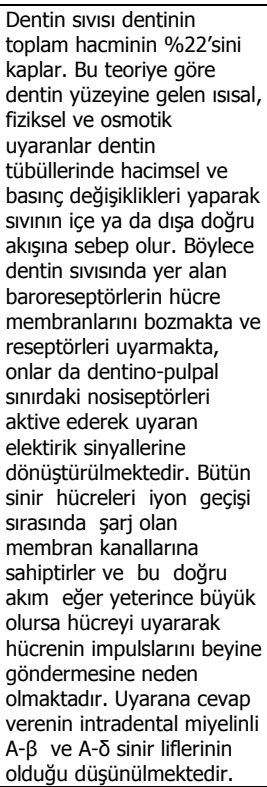 \\
\hline $\begin{array}{l}\text { Araştırma } \\
\text { Sonuçları }\end{array}$ & $\begin{array}{l}\text { Ağrıya neden } \\
\text { olan } \\
\text { maddelerin } \\
\text { dentin } \\
\text { yüzeyinde } \\
\text { ağrıya neden } \\
\text { olmamaları ve } \\
\text { elektron } \\
\text { mikroskobi } \\
\text { çalışmalarında } \\
\text { sinir uçlarının } \\
\text { daha çok pulpa } \\
\text { boynuzları } \\
\text { çevresinde } \\
\text { olacak şekilde, } \\
\text { dentin tübülleri } \\
\text { içinde çok kısa } \\
\text { bir mesafe } \\
\text { boyunca } \\
\text { penetre } \\
\text { olduklarının } \\
\text { gösterilmesi bu } \\
\text { teorinin } \\
\text { geçerliliğini } \\
\text { olumsuz yönde } \\
\text { etkilemektedir. }\end{array}$ & $\begin{array}{l}\text { Odontoblastik } \\
\text { uzantıların } \\
\text { nörotransmitter } \\
\text { saldığına dair } \\
\text { hiçbir kanıt } \\
\text { bulunamamışsır. } \\
\text { Brännström ve } \\
\text { Aström'ün } \\
\text { yaptıkları } \\
\text { çalışmada dentin } \\
\text { tabakası } \\
\text { tamamen } \\
\text { kaldırıı yerine } \\
\text { kan ve nekrotik } \\
\text { maddeler } \\
\text { bırakıldığında } \\
\text { dentin; teorinin } \\
\text { aksine daha da } \\
\text { hassasiyet } \\
\text { göstermiştir. Bu } \\
\text { teori } \\
\text { tartışılmakta olup } \\
\text { henüz kabul } \\
\text { görmemiştir. }\end{array}$ & $\begin{array}{l}\text { 19.yy.'da Gysi, dentin } \\
\text { tübülleri boyunca dışa } \\
\text { doğru sıvı akışı olduğunu } \\
\text { saptamış sıvı akışındaki } \\
\text { değişimlerin pulpal sinirleri } \\
\text { tetiklediği hipotezini ortaya } \\
\text { atmışır. Daha sonra } \\
\text { Brännström ve diğerleri en } \\
\text { çok kabul edilen teori } \\
\text { olmasını sağlayan } \\
\text { çalışmaları yayınlamıştır. } \\
\text { İnsan çalışmaları açığa } \\
\text { çıkan dentin yüzeyi } \\
\text { tarafından indüklenen ağrı } \\
\text { cevabı ile tübül yoğunluğu } \\
\text { arasında belirgin pozitif } \\
\text { korelasyonla, dentin } \\
\text { tübüllerinin açıklı̆ının } \\
\text { hassas dentin için önemli } \\
\text { bir özellik olduğunu } \\
\text { göstermiştir. Bukkal } \\
\text { servikal alanda, hassas } \\
\text { dişlerde hassas } \\
\text { olmayanlara oranla dentin } \\
\text { tübülleri } 8 \text { kat daha fazla } \\
\text { ve } 2 \text { kat daha geniş çapa } \\
\text { sahiptirler. Ayrıca Poiseuille } \\
\text { kanununa göre çap } 2 \text { kat } \\
\text { arttığında akış hızı } 16 \text { kat } \\
\text { artar. Dokunma, soğuk, } \\
\text { buharlaşma ve osmotik } \\
\text { (asit, tuz, şeker) uyaranlar } \\
\text { sıvının dışa doğru fizyolojik } \\
\text { olmayan akışına neden } \\
\text { olur, sıcak ise içe doğru bir } \\
\text { sıvı akıssına neden olur ve } \\
\text { sinir liflerini diğer } \\
\text { uyaranlara oranla daha az } \\
\text { uyarıp daha az ağrıya } \\
\text { neden olur. }\end{array}$ \\
\hline
\end{tabular}

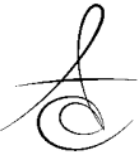




\section{Klinik Tanı ve Teşhis Yöntemleri}

DAH'nin multifaktöriyel oluşu ve semptomlarının diğer dental defekt ve patolojilerle benzerlik göstermesi, klinik tanı ve teşhisini zorlaştırmaktadır. ${ }^{8}$ DAH tanısında özellikle sondla muayene (Yeaple sondu), hava spreyi ile kurutma ve en çok soğuktan etkilendiği için soğuk testleri tercih edilir. Hasta hikayesi (ağrı karakteri, hangi uyaranlarla ağrı geliştiği, içsel ve dışsal asitlerin varlığı, diyet analizi) önemlidir ve ağrı şikayeti ile kliniğe başvuran hastadan detaylı anamnez almak gerekmektedir. Detaylı klinik muayene ile, ayıııcı tanı için diğer dental patoloji ve defektlerin varlığına (Tablo 3), açığa çıkmış dentin yüzeylerinin varlığına, uyaranlar ve ağrı arasındaki ilişkiye bakılmalıdır. Ağrının algılanması kişiden kişiye değişmekte olduğundan, hastanın rahatsızığını değerlendirmekte 1-10 arasında derecelendirmeyi içeren görsel karşılaştırma skalası (Visual Analog Scale/ VAS) veya hafif-ortaşiddetli olmak üzere ağrının tanımlandığı sözel tanımlama skalası (Verbal Rating Scale/VRS) kullanılır.

Tablo 3. DAH'nin ayırıcı tanısı.

\begin{tabular}{|l|}
\hline 1.Çatlak diş sendromu, \\
\hline 2.Kırık restorasyonlar \\
\hline 3.Hatalı pin uygulamaları \\
\hline 4.Travmatik okluzyondaki restorasyonlar \\
\hline 5.Yonga diş \\
\hline 6.Diş çürükleri, kök çürükleri \\
\hline 7.Postoperatif hassasiyet \\
\hline $\begin{array}{l}\text { 8.Restoratif tedavi veya belirli materyallere karşı } \\
\text { pulpal cevap, }\end{array}$ \\
\hline 9.Pulpanın reversible veya irreversible inflamasyonu \\
\hline 10.Restorasyonların kenar sızıntısı \\
\hline 11.Gingival inflamasyon \\
\hline 12.Palatogingival oluklar ve diğer mine invajinasyonları \\
\hline 13.Vital diş beyazlatma uygulamaları \\
\hline 14.Atipik odontalji \\
\hline
\end{tabular}

\section{Tedavide Kullanılan Materyal ve Yöntemler}

DAH tedavisinde ilk öncelik koruyucu tedavi ile predispozan faktörlerin ortadan kaldırımasıdır. Bu amaçla oral hijyen motivasyonu, doğru firçalama tekniğinin gösterilmesi, ağız diş bakımı için doğru ürünlerin seçilmesinde yardımcı olmak, hastaya ait beslenme alışkanlıklarının düzenlenmesi, sistemik veya psikolojik rahatsızıkların varlığında hastanın gerekli kliniklere yönlendirilmesi gerekmektedir. DAH'nin şiddetli semptomlarını gidermek, hastanın yaşam kalitesini iyileştirmek için uzun süreli etkili olacak tedavi seçeneklerine intiyaç vardır. Henüz terapötik altın standart olacak bir yöntem bulunamasa da pek çok materyal ve yöntem denenmiş ve günümüzde uygulanmaktadır (Tablo 4). ${ }^{19-66}$

Tedavi yöntemlerinde amaç; sinirsel iletimin azaltılması veya durdurulması (desensitizasyon) ve açık dentin tübüllerinin fiziksel olarak örtülmesidir. İdeal bir desensitizasyon ajanı; pulpaya iritan olmamalı, uygulama sırasında ağrı yaratmamalı, kolaylıkla uygulanabilmeli, etkinlik süresi uzun olmalı, hızlı etki etmeli, dişlerde renklenme yapmamalı, etkinliği kalıcı olmalıdır. ${ }^{60}$

Potasyum Nitrat: Son zamanlarda hassasiyeti gidermek amacı ile ağız bakım ürünlerinde; potasyum klorür $(\mathrm{KCl})$, potasyum sitrat $\left(\mathrm{C}_{6} \mathrm{H}_{7} \mathrm{O}_{7} \mathrm{~K}\right)$, potasyum oksalat $\left(\mathrm{K}_{2} \mathrm{C}_{2} \mathrm{O}_{4}\right)$ ve daha sıklkkla desensitizasyon ajanı olan potasyum nitrat $\left(\mathrm{KNO}_{3}\right)$ gibi potasyum tuzları bulunmaktadır. $\mathrm{KNO}_{3}$ 'In etki mekanizmasının oksidasyon ya da tübülleri kristalleştirerek sinir iletimini bloke etmesi şeklinde olduğu düşünülmüş ancak kanıtlanamamıştır. ${ }^{60} \mathrm{KNO}_{3}$ için düşünülen bir diğer mekanizma ise, $\left[\mathrm{K}^{+}\right]$artırması ve böylece sinirin yeniden repolarize olmasını engelleyecek şekilde depolarizasyonuna neden olmasıdır. $\mathrm{KCl}, \mathrm{C}_{6} \mathrm{H}_{7} \mathrm{O}_{7} \mathrm{~K}$ ve $\mathrm{KNO}_{3}$ içerikli hassasiyet giderici ürünlerin intradental sinirleri inhibe ederek görev gördüklerine dair inandırıcı kanıtların olmadığını bildirilmiştir. ${ }^{61}$

Gluteraldehit: Gluteraldehitin dentin sIvIsIndaki serum albüminle reaksiyona girerek çökelti oluşturup, tübülleri daralttığı veya tıkadığı düşünülmektedir. Gluteraldehitin düşük konsantrasyonlarda bile antibakteriyel etkinliği olduğu gösterilmiştir ancak fiksatif etkisi olduğundan yumuşak dokular uygulama sırasında korunmalıdır. Jel formu daha kontrollü bir çalışma sağlayabilir. ${ }^{62}$ Gluteraldehitin dentin tübüllerini tıkadığı histolojik olarak gösterilmiştir. ${ }^{63,64}$ Bazı ürünlerde gluteraldehite ek olarak bulunan HEMA'nın; dentine bağlanmada etkili hidrofilik bir monomer olduğu bildirilmiştir. ${ }^{62}$

Stronsiyum Tuzları: Stronsiyum tuzları (stronsiyum klorür, stronsiyum asetat), desensitize edici macunlarda 30 yılı aşkın bir süredir kullanılmaktadır. Çözünmeyen metallerin diş yüzeyine çökelmesini sağlayarak açık tübüllerde parsiyel ya da tam tıkama sağladıkları bildirilmiştir. ${ }^{65}$ Diğer alternatif açıklamalar, sinirlerin depolarizasyonunu veya stronsiyumun dentine yüksek afinitesi ile birlikte hidroksiapatit yapısındaki kalsiyumun yerine geçerek demineralize 
Tablo 4. DAH tedavisinde kullanılan yöntem ve materyallerle ilgili çalışmalar.

\begin{tabular}{|c|c|c|c|}
\hline Yayın & Materyal & $\begin{array}{c}\text { Değerlendirme Kriterleri } \\
\text { /Zamanları }\end{array}$ & Sonuç \\
\hline Schiff ve ark. ${ }^{19}$ & $\begin{array}{l}\% 5 \mathrm{KNO}_{3}, \% 1.3 \text { çözünebilir pirofosfat, } \% 1.5 \\
\text { PVM/MA kopolimer ve } \% 0.243 \text { sodyum } \\
\text { monoflorit fosfat/ } \mathrm{KNO}_{3} \text { içermeyen diş macunları }\end{array}$ & $\begin{array}{l}\text { Buharlaşma, dokunma ve termal / } 6 \text { ve } \\
12 \text { hafta sonra }\end{array}$ & $\% 5$ potasyum nitrat içeren $6-8$ hafta daha etkili \\
\hline Pereira ve ark. ${ }^{20}$ & $\% 3 \mathrm{KNO}_{3}, \% 2 \mathrm{Naf} / \% 2 \mathrm{NaF}$ gargaralar & $\begin{array}{l}\text { Dokunma ve soğuk hava / } 2 \text { ve } 6 \text { hafta } \\
\text { sonra }\end{array}$ & $\begin{array}{l}2 \text { ajan da etkili ancak } 6 \text { hafta da } \mathrm{KNO}_{3} \text { içeren daha } \\
\text { etkili }\end{array}$ \\
\hline Pradeep ve ark. $^{21}$ & $\begin{array}{l}\% 5 \mathrm{KNO}_{3} / \% 5 \text { kalsiyum-sodyum fosfosilikat / } \\
\% 3.85 \text { amin florür / placebo diş macunları }\end{array}$ & Soğuk su - hava/ 2 ve 6 hafta sonra & $\begin{array}{l}\text { 2. haftada benzer etkinlik, } 6 . \text { haftada } \% 5 \text { kalsiyum- } \\
\text { sodyum fosfosilikat daha etkili }\end{array}$ \\
\hline $\begin{array}{l}\text { Wara-aswapati ve } \\
\text { ark. }\end{array}$ & $\begin{array}{l}\% 0.3 \text { Triclosan, } \% 5 \mathrm{KNO}_{3}, 0.76 \% \text { sodyum } \\
\text { monoflorofosfat (SMFP) / Triclosan içermeyen } \\
\text { aynı ürün/ sadece } 0.76 \% \text { SMFP içeren , diş } \\
\text { macunları }\end{array}$ & $\begin{array}{l}\text { Diş eti kanama indeksi (GBI), Plak } \\
\text { İndeksi (PI)/ } \\
\text { Uygulama öncesi, } 4 \text { ve } 12 \text { hafta sonra }\end{array}$ & $\begin{array}{l}\text { Triclosan içerenin etkinliği } 4 \text {. haftada daha fazla } \\
\text { bulunmuş ve etkinlik } 12 \text { hafta devam etmiştir. }\end{array}$ \\
\hline Guentsch ve ark. ${ }^{23}$ & $\begin{array}{l}\text { Biyomimetik mineralizasyon (BIMIN)(Heraeus } \\
\text { Kulzer GmbH, Hanau, Almanya) ve Gluma } \\
\text { Desensitizer (GD)(Heraeus Kulzer, Hanau, } \\
\text { Almanya) }\end{array}$ & $\begin{array}{l}\text { SEM incelemesi / Uygulama öncesi, } 2 \\
\text { gün, } 3 \text { ve } 12 \text { ay sonra }\end{array}$ & $\begin{array}{l}\text { Her iki materyalde de } 3-12 \text { ayda dentin tübüllerinde } \\
\text { açılma ancak tek seansla } 12 \text { ay etkinlik }\end{array}$ \\
\hline $\begin{array}{l}\text { Minkoff ve } \\
\text { ark. } 24\end{array}$ & $\% 10$ stronsiyum klorid hekzahidrat/ placebo & $\begin{array}{l}\text { Termal, soğuk hava, subjektif cevap / } \\
\text { Uygulama öncesi, } 2,4,8 \text { ve } 12 \text { hafta } \\
\text { sonra }\end{array}$ & $\begin{array}{l}\text { \%10 stronsiyum klorid hekzahidrat etkinliği } 2 \text {. haftada } \\
\text { başlayıp zaman içinde artarak } 12 \text { hafta boyunca etkili } \\
\text { olmustur. }\end{array}$ \\
\hline Hughes ve ark. ${ }^{25}$ & $\begin{array}{l}\% 8 \text { stronsiyum asetat, } 1040 \mathrm{ppm} \mathrm{NaF} / \% 8 \\
\text { arjinin, kalsiyum karbonat, } 1450 \mathrm{ppm} \text { SMFP }\end{array}$ & $\begin{array}{l}\text { Buharlaşma ve dokunma /Uygulama } \\
\text { öncesi, 14., 28. ve } 56 . \text { gün }\end{array}$ & $\begin{array}{l}\text { 56. günde dokunmaya karşı \%8 stronsiyum asetatın } \\
\text { daha etkili olması dışında hiçbir zaman aralığında } \\
\text { ürünler arasında fark bulunamamıştır. }\end{array}$ \\
\hline Mason ve ark. ${ }^{26}$ & $\begin{array}{l}\text { Silika bazda \%8 stronsiyum asetat, } 1040 \text { ppm } \\
\text { florür/ Silika bazda } 1450 \mathrm{ppm} \text { florür }\end{array}$ & $\begin{array}{l}\text { Buharlaşma ve dokunma/Uygulamadan } \\
\text { hemen sonra ve } 3 \text { gün sonra }\end{array}$ & $\begin{array}{l}\text { Her iki değerlendirmede de \%8 stronsiyum asetat, } \\
1040 \text { ppm florür daha etkili bulunmuştur. }\end{array}$ \\
\hline Parkinson ve ark. ${ }^{27}$ & $\begin{array}{l}\text { \%8 stronsiyum asetat / } \\
\text { pro-arjinin / Deiyonize su }\end{array}$ & $\begin{array}{l}\text { SEM / } 30 \text { sn veya } 10 \mathrm{dk} \text { greyfurt } \\
\text { suyunda bekletilince }\end{array}$ & $\begin{array}{l}\text { Stronsiyum asetat dentin tübüllerini tıkamada daha } \\
\text { etkili bulunmuştur. }\end{array}$ \\
\hline Ni ve ark. $^{28}$ & Kalay içerikli $\mathrm{NaF} / \mathrm{KNO}_{3}$ & $\begin{array}{l}\text { Dokunma ve termal / Uygulama öncesi, } \\
4 \text { ve } 8 \text { hafta sonra }\end{array}$ & $\begin{array}{l}\text { Her iki materyal de uyaranlara karşı cevabı azaltmış } \\
\text { ancak etkinlikleri arasında fark bulunamamışıı. }\end{array}$ \\
\hline Schiff ve ark. ${ }^{29}$ & $\begin{array}{l}\text { silika bazda } \% 5 \mathrm{KNO}_{3}, \% 0.454 \text { kalay florür / } \\
\text { dikalsiyum fosfat bazda } \% 5 \mathrm{KNO}_{3}, 0.76 \% \text { SMFP }\end{array}$ & $\begin{array}{l}\text { Dokunma ve buharlaşma/ } 4 \text { ve } 8 \text { hafta } \\
\text { sonra }\end{array}$ & $\begin{array}{l}\text { Kalay florür içerikli ürün 4-8 haftada daha etkili } \\
\text { bulunmuştur. }\end{array}$ \\
\hline Aparna ve ark. ${ }^{30}$ & $1.23 \%$ APF jel İyontforez / Scotchbond & $\begin{array}{l}\text { Dokunma, buharlaşma ve termal / } \\
\text { Uygulamadan hemen sonra ve } 2 \text { hafta } \\
\text { sonra }\end{array}$ & $\begin{array}{l}\text { Her iki ajan da etkili olmuş fakat APF kombine } \\
\text { iyontoforez daha etkili bulunmuştur. }\end{array}$ \\
\hline Kern ve ark. ${ }^{31}$ & İyontoforez kombine $\mathrm{NaF}$ / sadece $\mathrm{NaF}$ & $\begin{array}{l}\text { Dokunma ve buharlassma/ } \\
\text { Uygulamadan hemen sonra ,1., 3. ve } \\
\text { 6. ay }\end{array}$ & $\begin{array}{l}\text { NaF tek başına etki etmemiş, İyontoforez ile hemen } \\
\text { etki edip } 3 \text { ay etkisini korumuş. } 6 \text {. ayda etkinliğini } \\
\text { kaybetmiştir. }\end{array}$ \\
\hline Singal ve ark..$^{32}$ & \%2 NaF İyontoforez / HEMA-G & $\begin{array}{l}\text { Buharlaşma ve termal/ Uygulamadan } \\
\text { hemen sonra ve } 2 \text {. hafta sonra, } 1 \text {. ve } \\
\text { 3. ay }\end{array}$ & $\begin{array}{l}\text { Her ikisi de etkili olmuş ancak 1-3 aylık süreçte } \\
\text { iyontoforez daha etkili bulunmuştur. }\end{array}$ \\
\hline Gillam ve ark..$^{33}$ & $\begin{array}{l}\text { Oksalik asit / ferrik oksalat / aluminyum oksalat } \\
\text { ve potasyum oksalat }\end{array}$ & SEM/ Uygulamadan hemen sonra & $\begin{array}{l}\text { İlk } 3 \text { ajan arasında fark bulunmazken, } \mathrm{K}_{2} \mathrm{C}_{2} \mathrm{O}_{4} \text {, tübülleri } \\
\text { tıkamada daha az etkili bulunmuştur. }\end{array}$ \\
\hline Yiu ve ark. $^{34}$ & $\begin{array}{l}\text { Bisblock (Bisco, IL, ABD) ve Superseal } \\
\text { (Phoenix Dental, MI, ABD ) sonrası One-Step } \\
\text { (OS) (Bisco, IL, ABD) / Single Bond (SB)(3M } \\
\text { ESPE, MN, ABD) / OptiBond Solo Plus (OB)(Kerr } \\
\text { Co., CA, ABD) ve Prime\&Bond NT } \\
\text { (PB)(Dentsply, Konstanz, Almanya) }\end{array}$ & $\begin{array}{l}\text { SEM ve TEM/ Uygulamadan hemen } \\
\text { sonra }\end{array}$ & $\begin{array}{l}\text { Oksalatlar; OB ve PB'nin dentine bağlanma } \\
\text { kuvvetlerini azaltırken OS ve SB'un bağlanma } \\
\text { kuvvetlerini değiştirmemiştir. }\end{array}$ \\
\hline $\begin{array}{l}\text { Vachiramon ve } \\
\text { ark. }^{35}\end{array}$ & $\begin{array}{l}\text { Bisblock (Bisco, Inc., IL, ABD) ve Superseal } \\
\text { (Phoenix Dental, MI, ABD) sonrası Adper Single } \\
\text { Bond(3M ESPE, MN, ABD) }\end{array}$ & TEM/ Uygulamadan 3 ay sonra & $\begin{array}{l}\text { Single Bond uygulandığında bağlanma kuvvetlerinin } \\
\text { azaldığı ve nanosızıntının arttığı gözlenmiştir. }\end{array}$ \\
\hline Lehmann ve ark. ${ }^{36}$ & $\begin{array}{l}\text { MS Coat (Sun Medical, Japonya) / Viva Sens ( } \\
\text { Ivoclar Vivadent, Liechtenstein, Almanya )/ } \\
\text { Tubulicid (DentalTherapeutics, İsveç)veya } \\
\text { Gluma (Heraeus Kulzer, Almanya)sonrası } \\
\text { Optibond FL (Kerr, ABD)/Clearfil SE Bond } \\
\text { (Kuraray, Japonya) veya Xeno III (Dentsplay, } \\
\text { Almanya) }\end{array}$ & T30K/ Uygulamadan hemen sonra & $\begin{array}{l}\text { Gluma ve Ms Coat, Clearfil SE Bond dışındaki } \\
\text { adeziv sistemlerin bağlanma kuvvetlerini azaltırken } \\
\text { Tubulicid ve Viva Sens'in hiçbir adezivin bağlanma } \\
\text { kuvvettini etkilemediği saptanmıştır }\end{array}$ \\
\hline Huh ve ark. ${ }^{37}$ & $\begin{array}{l}\text { SuperSeal (Phoenix Dental, ABD) / Ms Coat } \\
\text { (Sun Medical, Japonya)/ Gluma (Heraeus } \\
\text { Kulzer, Almanya) ve Copalite Varnish (Cooley \& } \\
\text { Cooley Ltd, ABD)sonrası Panavia F (Kuraray, } \\
\text { Tokyo, Japonya) }\end{array}$ & $\begin{array}{l}\text { Model } 6022 \text { ve SEM/ Uygulamadan } \\
\text { hemen sonra }\end{array}$ & $\begin{array}{l}\text { Panavia F'in makaslama kuvvetlerine dayanımını } \\
\text { azaltmayan tek ajanın Superseal olduğu saptanmıştır }\end{array}$ \\
\hline Hamlin ve ark. $^{38}$ & $\begin{array}{l}\% 8 \text { arjinin ve kalsiyum karbonat içeren pat ve } \\
\text { Nupro (Dentsply Professional, } \mathrm{PA}, \mathrm{ABD} \text { ) }\end{array}$ & $\begin{array}{l}\text { Dokunma ve buharlaşma/ Diş taşı } \\
\text { temizliği öncesi uygulamada }\end{array}$ & $\begin{array}{l}\text { İşlem sonrasında her iki ajanda da hassasiyet azalmış } \\
\text { ancak arjininli pat daha etkin bulunmuştur. }\end{array}$ \\
\hline Schiff ve ark. ${ }^{39}$ & $\begin{array}{l}\% 8 \text { arjinin ve kalsiyum karbonat içeren pat ve } \\
\text { Nupro (Dentsply Professional, PA, ABD) }\end{array}$ & $\begin{array}{l}\text { Dokunma ve buharlaşma/ Diş taşı } \\
\text { temizliğinden sonra uygulandığnda, } \\
\text { uygulamadan } 4 \text { ve } 12 \text { hafta sonra }\end{array}$ & $\begin{array}{l}\text { 4. haftada arjininde daha fazla etkinlik gözlenmiş, diş } \\
\text { taşı temizliği sonrası ve } 12 \text {. haftada iki ajanın } \\
\text { etkinliğinde fark bulunamamıştır }\end{array}$ \\
\hline Boneta ve ark. ${ }^{40}$ & $\begin{array}{l}\text { Arjininli diş macunu + arjininli ağız gargarası / } \\
\mathrm{KNO}_{3} \text { içerikli diş macunu }+\mathrm{KNO}_{3} \text { içerikli ağız } \\
\text { gargarası ve } \mathrm{NaF} \text { içerikli diş macunu + } \\
\text { monoflorofosfat içerikli ağız gargarası }\end{array}$ & $\begin{array}{l}\text { Dokunma ve buharlaşma/ Uygulama } \\
\text { öncesi, } 2,4 \text { ve } 8 \text { hafta sonra }\end{array}$ & Arjinin içerikli rejim daha etkili bulunmuştur. \\
\hline Boneta ve ark. ${ }^{41}$ & $\begin{array}{l}\% 0.8 \text { arjinin iç̧erikli ağız gargarası / \%2.4 } \\
\mathrm{KNO}_{3} \text { içerikli ağız gargarası ve } \% 0.05 \mathrm{NaF} \\
\text { içerikli ağız gargarası }\end{array}$ & $\begin{array}{l}\text { Dokunma ve buharlaşma/ Uygulama } \\
\text { öncesi, } 30 \mathrm{dk} \text { sonra, 2, } 4 \text { ve } 6 \text { hafta } \\
\text { sonra }\end{array}$ & $\begin{array}{l}\text { İlk } 30 \text { dkda herhangi bir etki gözlenmezken, } 2 \text {. } \\
\text { haftadan itibaren } 6 \text { hafta boyunca arjininli gargaranın } \\
\text { etkinliğinin devam ettiği ve diğer ajanlara oranla daha } \\
\text { fazla olduğu bildirilmiștir }\end{array}$ \\
\hline Mitchell ve ark. $^{42}$ & $\begin{array}{l}\text { Uygun taşıyıI I sıvılar içersindeki sol ve jel } \\
\text { biyoaktif camlar ve sadece taşıyııı sıvılar }\end{array}$ & $\begin{array}{l}\text { SEM ve hidrolik iletkenlik testleri / } \\
\text { Çeșitli sIVI ve firçalama maruziyeti } \\
\text { sonrası } 96 \text {. ve } 168 \text {. Saat }\end{array}$ & $\begin{array}{l}\text { Biyoaktif cam içerikli olanların } 96 \text {. ve 168. saatlerde } \\
\text { belirgin şekilde dentin boyunca sıvı iletkenliğini } \\
\text { azalttı̆ı saptanmış, Non-biyoaktif parçacıkların } \\
\text { eklendiği taşıyııı ise taşıyııının tek başına } \\
\text { olduklarından daha fazla azalma sağlamamıștır. }\end{array}$ \\
\hline
\end{tabular}


Tabo 4'ün devamı

\begin{tabular}{|c|c|c|c|}
\hline Lynch ve ark. ${ }^{43}$ & $\begin{array}{l}\text { Florür içeren çok bileşenli biyoaktif camlar ve } \\
\text { florür içermeyenler }\end{array}$ & $\begin{array}{l}\text { SEM, XRD, İnfrared Spektroskopi ve } \\
\text { Plazma Emisyon Spektroskopisi / } 1 \\
\text { hafta sonra }\end{array}$ & $\begin{array}{l}\text { Fosfat, içeriğindeki artış daha hızlı ve daha fazla apatit } \\
\text { oluşturmuştur. Stronsiyum, potasyum, çinko ve florür } \\
\text { iyonlarıın salınımının çürük engelleyici, sinirleri } \\
\text { desensitize edici ve antibakteriyel özellik kazandırdığı, } \\
\text { floroapatit oluşumunun hidroksiapatit oluşumundan } \\
\text { daha fazla olduğu, gerekli en az pH yükselişi ile apatit } \\
\text { oluşabildiği saptanmıştır. }\end{array}$ \\
\hline Chen ve ark. ${ }^{44}$ & $\begin{array}{l}\text { Konvansiyonel (Gözeneksiz) biyoaktif cam / } \\
\text { Gözenekli biyoaktif cam }\end{array}$ & $\begin{array}{l}\text { XRD, SEM, FTIR / Uygulamadan hemen } \\
\text { sonra }\end{array}$ & $\begin{array}{l}\text { İkisinde de major kristalit fazın monokalsiyum fosfat } \\
\text { monohidrat olduğu, gözenekli camların } 50 \mu \mathrm{mm} \\
\text { derinliğe kadar ilerlediği ve gözeneksiz camlara göre } \\
\text { kısa reaksiyon süresi ve uygulama kolaylığı ile tedavi } \\
\text { için kullanıma daha uygun olduğu sonucuna } \\
\text { varılmıştır. }\end{array}$ \\
\hline Tirapelli ve ark. $^{45}$ & $\begin{array}{l}\text { Sensi Kill (DFL, RJ, Brezilya) / Sensodyne } \\
\text { (Glaxo Smithkline, RJ, Brezilya) /Biosilikat \%1lik } \\
\text { susuz jel içinde ve 1:10 oranında distile su ile } \\
\text { karıştırımış Biosilikat (Vitrovita, Sao Carlos, } \\
\text { Brezilya) }\end{array}$ & $\begin{array}{l}\text { Buharlaşma/ Uygulama öncesi, tedavi } \\
\text { boyunca her hafta ve } 6 \text { ay sonra }\end{array}$ & $\begin{array}{l}4 \text { ürün de etkili olmuştur. Distile su ile biosilikat } \\
\text { karışımı diğerlerine göre daha hızı ve daha fazla etki } \\
\text { etmiştir. }\end{array}$ \\
\hline $\begin{array}{l}\text { Ananthakrishna ve } \\
\text { ark. }^{46}\end{array}$ & $\begin{array}{l}\text { Senolin (Warren, Mumbai, Hindistan) / } \\
\text { Denshield (NovaMin Technology Inc., Alachua, } \\
\text { FL, ABD) }\end{array}$ & $\begin{array}{l}\text { Buharlaşma ve termal/ Uygulama } \\
\text { öncesi, 2, } 4 \text { ve } 6 \text { hafta sonra }\end{array}$ & Denshield'in etkinliği daha fazla bulunmuştur. \\
\hline Bakry ve ark. ${ }^{47}$ & $\begin{array}{l}45 \mathrm{~S} 5 \text { bioglass pat/ Caviton (GC, Japonya)/ Fuji } \\
\text { I (GC, Tokyo, Japonya) ve Superseal (Phoenix } \\
\text { Dental, Fenton, MI, ABD) }\end{array}$ & MTT/ Uygulamadan hemen sonra & $\begin{array}{l}\text { Sitotoksisitelerinde farklllık olmadığı ve } 455^{\prime} 5^{\prime} \text { in pulpal } \\
\text { hücrelerde minimal toksik etki gösterdiği saptanmıştır. } \\
\mathrm{CO}_{2} \text { lazer dentin ile etkileşimini artırmıştır. }\end{array}$ \\
\hline Forsback ve ark. ${ }^{48}$ & S53P4 biyoaktif cam & $\begin{array}{l}\text { SEM-EDX ve XPS/ } \\
\text { Uygulamadan hemen sonra, } 15 \mathrm{dk}, 24 \\
\text { saat sonra }\end{array}$ & $\begin{array}{l}\text { Dentin yüzeyinde kalsiyum ve fosfor dizilimi ile silikon } \\
\text { yapı gözlenmiş. S53P4 camı kendi kendine silika } \\
\text { zengin yüzeyde kalsiyum fosfat tabakası oluşturduğu } \\
\text { böylece biyomineralizasyon için yeterli bir silika ve } \\
\text { kalsiyum kaynağı olduğu belirlenmiștir. }\end{array}$ \\
\hline $\begin{array}{l}\text { Polderman ve } \\
\text { ark. }^{49}\end{array}$ & $\begin{array}{l}\text { Fuji VII (GC Europe, Leuven, Belçika) / Gluma } \\
\text { Desensitizer (Heraeus Kulzer, Hanau, Almanya) }\end{array}$ & $\begin{array}{l}\text { Buharlaşma ve telefon görüşmesi / } \\
\text { Uygulama öncesi ve uygulamadan } \\
\text { hemen sonra, } 1 \text {, } 3 \text { ve } 25.2 \text { ay sonra }\end{array}$ & $\begin{array}{l}\text { Fuji VII , Gluma Desensitizer'dan } 3 \text { ay sonunda daha } \\
\text { etkili olmuş ve } 25.2 \text { ay boyunca etkinliğini } \\
\text { sürdürmüştür. }\end{array}$ \\
\hline Ünlü ve ark. $^{50}$ & $\begin{array}{l}\text { Single Bond (3M Dental Products, St Paul, ABD) } \\
\text { /Prime Bond NT (Dentsplay DeTrey GmbH, } \\
\text { Konstanz, Almanya) / Gluma Desensitizer } \\
\text { (Heraeus Kulzer, Inc., South Bend,ABD) ve } \\
\% 1.23 \mathrm{APF}\end{array}$ & $\begin{array}{l}\text { Buharlaşma ve termal/ } 1,7 \text { ve } 15 \text { gün, } \\
1,3 \text { ve } 6 \text { ay sonra }\end{array}$ & $\begin{array}{l}\text { Single Bond Prime\&Bond NT'e oranla daha etkili } \\
\text { bulunmuştur ancak en etkili ajan Gluma Desensitizer } \\
\text { olmuştur. }\end{array}$ \\
\hline Akca ve ark. ${ }^{51}$ & $\begin{array}{l}\text { Adper Single Bond (3M ESPE,ABD)/ Nupro } \\
(\mathrm{NaF})(\text { Dentsplay ABD) }\end{array}$ & $\begin{array}{l}\text { Buharlaşma ve dokunma/ Diş replika } \\
\text { ve SEM }\end{array}$ & $\begin{array}{l}\text { Klinik olarak iki ajan arasında fark gözlenmezken SEM } \\
\text { incelemesi adezivin flor jelinden daha fazla tübülü } \\
\text { kapattığını göstermiştir. }\end{array}$ \\
\hline Yu ve ark. ${ }^{52}$ & $\begin{array}{l}\text { iBond (Heraeus Kulzer, Hanau, Almanya) / } \\
\text { Xeno V (Dentsplay, Konstanz, Almanya) / } \\
\text { Gluma (Heraeus Kulzer, Wehrheim,Almanya) / } \\
\text { Biflourid } 12 \text { (Voco, Cuxhaven, Almanya) ve } \\
\text { placebo (su) }\end{array}$ & $\begin{array}{l}\text { Dokunma ve termal/ Uygulama öncesi } \\
\text { ve uygulamadan hemen sonra, } 1 \text { ay } \\
\text { sonra }\end{array}$ & $\begin{array}{l}\text { Biflourid } 12 \text { haricinde tüm ajanlar mekanik uyaranlara } \\
\text { karşı etkinliğini korumuştur. Gluma Desensitizer ve } \\
\text { iBond'da } 1 \text { ay içerisinde termal uayaranlara karşı } \\
\text { cevapta azalma devam ederken, başlangıca göre daha } \\
\text { az olsa da Xeno V'de az miktarda, placebo ve Biflourid } \\
12 \text { 'de artış gözlenmiştir. }\end{array}$ \\
\hline Birang ve ark. ${ }^{53}$ & Nd:YAG /Er:YAG & $\begin{array}{l}\text { Dokunma/ Uygulama öncesi ve } \\
\text { uygulamadan hemen sonra, 1, } 3 \text { ve } 6 \\
\text { ay sonra }\end{array}$ & $\begin{array}{l}\text { Nd:YAG , Er:YAG lazere göre daha etkili bulunmuş, } 6 \\
\text { ay boyunca etkinlik devam etmiştir. }\end{array}$ \\
\hline Schwarz ve ark. ${ }^{54}$ & Er:YAG / Dentin Protector & $\begin{array}{l}\text { Buharlaşma ve termal/ Uygulama } \\
\text { öncesi ve uygulamadan hemen sonra, } \\
1 \text { hafta, } 2 \text { ve } 6 \text { ay sonra }\end{array}$ & Er:YAG lazer daha etkili bulunmuştur. \\
\hline Yılmaz ve ark. ${ }^{55}$ & Er;Cr:YSGG / placebo & $\begin{array}{l}\text { Buharlaşma ve PI/1 hafta, } 1 \text { ve } 3 \text { ay } \\
\text { sonra }\end{array}$ & $\begin{array}{l}\text { Er;Cr:YSGG lazerin } 3 \text { ay boyunca etkinliğini koruduğu } \\
\text { gözlenmiștir }\end{array}$ \\
\hline Yılmaz ve ark. ${ }^{56}$ & $\begin{array}{l}\text { Er;Cr:YSGG / diyod lazer / tedavi } \\
\text { uygulanmayan grup }\end{array}$ & $\begin{array}{l}\text { Buharlaşma/ Uygulama } \\
\text { öncesi,uygulamadan hemen sonra, } 1 \\
\text { hafta, } 1 \text { ve } 3 \text { ay sonra }\end{array}$ & $\begin{array}{l}\text { İki lazer de etkili bulunmuş, çalışma boyunca bu } \\
\text { etkinlik devam etmiş ve birbirlerine göre belirgin bir } \\
\text { fark göstermemişlerdir. }\end{array}$ \\
\hline Akca ve ark. ${ }^{57}$ & Diyod lazer/ placebo & $\begin{array}{l}\text { Dokunma ve buharlaşma/ Uygulama } \\
\text { öncesi ve uygulamadan hemen sonra, } \\
1 \text { ay boyunca her hafta }\end{array}$ & Diyod lazer 4 hafta boyunca etkili bulunmuştur. \\
\hline Yilmaz ve ark. ${ }^{58}$ & $\begin{array}{l}\text { Diyod lazer / placebo diyod lazer/ NaF vernik / } \\
\text { placebo } \mathrm{NaF}\end{array}$ & Buharlaşma/ 1 hafta, 1,3 ve 6 ay sonra & $\begin{array}{l}\text { Diyod lazer NaF vernik ve placebo gruplarına oranla } \\
\text { daha etkili bulunmuştur. }\end{array}$ \\
\hline Lopes ve ark. ${ }^{59}$ & $\begin{array}{l}\text { Gluteraldehit / Nd:YAG lazer / } \\
\text { Nd:YAG ile Gluteraldehit }\end{array}$ & $\begin{array}{l}\text { Dokunma ve termal/ } 5 \mathrm{dk}, 1 \text { hafta, } 1, \\
3 \text { ve } 6 \text { ay sonra }\end{array}$ & $\begin{array}{l}6 \text { ay boyunca } 3 \text { yöntem de etkili olmuş ancak Nd:YAG } \\
\text { ve gluteraldehitin birlikte uygulanışı daha hızlı ve daha } \\
\text { uzun süreli etki göstermiştir. }\end{array}$ \\
\hline
\end{tabular}


dentini güçlendirdiği şeklinde yapılmıştır. Stronsiyum asetat'ın tübül tıkayıcı etkisi doğrulanmış ancak desensitize edici özelliğin ürünlerdeki silika abrazivlerden kaynaklı olabileceği belirtilmiştir. ${ }^{66}$ Hyposen desensitizer (Lege artis Pharma GmbH, Dettenhausen, Almanya) ise yapısındaki stronsiyum klorürün stronsiyum apatite dönüşmesi ile etki etmektedir. ${ }^{62} \% 10$ Strontium chloride hexahydrate içeren diş macununun (Sensodyne Original, GlaxoSmithKline, Rio de Janeiro, Brazil) tübüllerde $86 \mu m^{\prime} y e$ kadar penetre olduğu gösterilmiştir. ${ }^{67}$

Florürler ve İyontoforez: Florür bileşikleri diş yüzeyinde tükürükteki $\mathrm{Ca}^{++}$ve $\mathrm{PO}_{4}$ iyonları ile birleşerek floroapatit kristallerini oluşturur. Böylece dentin tübüllerinin tıkanmasını sağlayarak ve dekalsifikasyonlara karşı dentinin direncini artırarak çürüğe ve diş aşınmalarına karşı korumada başarı sağlarlar. ${ }^{68,69}$ Hasta tarafından florür içeren diş macunu ve/veya gargaraların kullanımı, hekim tarafından jel veya vernik halinde veya iyontoforez yöntemi ile uygulanabilir. ${ }^{2}$

Hassasiyet giderici olarak kullanılan diş macunlarına sodyum monoflorofosfat $\left(\mathrm{Na}_{2} \mathrm{PO}_{3} \mathrm{~F}\right)$, sodyum florür $(\mathrm{NaF})$ ve kalay (stannöz) florür $\left(\mathrm{SnF}_{2}\right)$ gibi florür bileşikleri eklenmiştir. $\mathrm{NaF}$ ve $\mathrm{Na}_{2} \mathrm{PO}_{3} \mathrm{~F}$, kalsiyumla etkinliklerini kaybederken $\mathrm{SnF}_{2}$ biyolojik aktivitesini sürdürmektedir. ${ }^{70}$ Ağız gargaraları uygulandıktan sonra diş yüzeyinde kalsiyum florür $\left(\mathrm{CaF}_{2}\right)$ tabakasının oluştuğu ve diş yüzeyinden çözündüğü ve laktat üretimini belirgin olarak azalttığı da bildirilmiştir. ${ }^{68}$

Topikal florürler piyasada, $\% 1.23$ asidüle fosfat florür (APF) jel ya da köpük formunda (12.300 ppm F) ve nötr \%2 NaF (9.040 ppm F) olarak bulunmaktadır. Yüksek konsantrasyondaki florür jellerinin mine erozyonlarında yeniden sertleşme (rehardening) yapabildiği gösterilmiştir. ${ }^{2}$

Florürlü verniklerin kullanılması hastaların şikayetini kısa süreli de olsa geçirebilmektedir ancak; aşınma nedeniyle 6 ayda bir tekrar uygulanması gerekmektedir. NaF verniklerin kademeli etkisi, $\mathrm{NaF}$ ile dentin sıvısının $\mathrm{Ca}^{++}$iyonları arasında meydana gelen reaksiyona ve bunun dentin tübüllerinin ağızlarında biriken $\mathrm{CaF}_{2}$ kristallerini oluşturmasına bağlıdır ancak kristal boyutu küçük olduğu sürece tek bir $\mathrm{NaF}$ uygulaması dentin tübüllerinin çapını daraltmakta efektif olmayacaktır. Piyasada farklı florür vernikleri (Duraphat, Bifluorid, Cervitec, Flour Protector (FP)) bulunmaktadır. Küçük çocuklarda aşırı flor yutulmasına karşı \%0.1'lik florür içeren FP geliştirilmiştir. İçeriğindeki çözücülerin uygulama sonrasında buharlaşmasıyla diş yüzeyindeki $\left[\mathrm{F}^{+}\right]^{\prime}$ nun 10 kat arttığı bildirilmiştir. ${ }^{30}$

İyontoforez yöntemi düşük amperli elektrik akımından yararlanarak iyonların doku içerisine girmelerini sağlar. İyontoforez ile tedavi edilen dişlerdeki $\left[\mathrm{F}^{+}\right]$, florun topikal olarak uygulandığı dişlerdekine oranla 2 kat daha fazladır. Artan $\left[\mathrm{F}^{+}\right], \mathrm{CaF}_{2}$ çökelmesini sağlayarak dentin tübülleri tıkanmakta ve DAH engellenmektedir. ${ }^{2}$

Oksalatlar: Oksalat bileşikleri dentindeki $\mathrm{Ca}^{++}$ iyonlarıyla reaksiyona girerek dentin tübüllerini tıkayan çözünmeyen kalsiyum oksalat kristallerini oluştururlar. Dentini kaplayan doğal smear tabakasının üzerine oksalat bileşiklerinin uygulanmasıyla smear tabakasının yerine aside dirençli yeni bir oksalat kristali tabakası oluşturmakta ve orijinal smear tabakasının fonksiyonunu yerine getirmektedir. ${ }^{62} \mathrm{Bu}$ ajanlar genel olarak ferrik oksalat, potasyum oksalat, oksalik asit, alüminyum oksalat ve fotokompleks içeren oksalat formunda bulunmaktadır. \%6'lık ferrik oksalat, \%30'luk dipotasyum oksalat ve \%3'lük monohidrojen-monopotasyum gibi oksalat bileşikleri hassasiyeti azaltmada etkili bulunmuşlardır. ${ }^{71} \mathrm{D} /$ Sense Crystal (Centrix, Shelton, $\mathrm{CT}, \mathrm{ABD}$ ) içeriğindeki $\mathrm{KNO}_{3}$ birlikte çift yönlü etki ederek DAH'ni giderir. BisBlock (BISCO, Inc. Schaumburg, IL, ABD) ise diş yüzeyi \%32 fosforik asitle 15 sn pürüzlendirildikten sonra kurutulan yüzeye 30 sn süreyle uygulanır ve üzerine adeziv sürülerek 20 sn ışık uygulanır. Adezivler, kalsiyum oksalat kristalleri arasına sızar ve polimerizasyon sırasında bunları hapsederek kristallerin yer değiştirmesini engeller ve daha uzun süreli etki gösterir. ${ }^{62} \% 3$ monohidrojen-monopotasyum oksalatın yararlı etkileri olduğu ve oksalat tedavisinde tercih edilmesi gereken ilk ajan olduğu bildirilmiştir. ${ }^{71} \mathrm{DAH}$ tedavisinde gastrik iritasyondan dolayı oksalatlar dikkatli kullanılmalıdır. ${ }^{72}$

Oksalat içerikli ajanların adezivlerin dentine bağlanma kuvvetlerini nasıl etkilediği ile ilgili yapılan çalışmalar çok farklı sonuçlar gösterdiğinden hekimin, seçtiği oksalat içerikli ajan ve adezivin türüne göre karar vermesi, bu ürünlerle yapılan çalışmaları dikkate alması gerekmektedir.

Arjininler: Tükürüğün DAH'ni doğal olarak azalttığının anlaşılması ile bileşenleri, fizyolojik $\mathrm{pH}^{\prime} \mathrm{da}$ (6.5-7.5) pozitif yüklü bir amino asit olan arjinin, $\mathrm{pH}$ 
tamponlayıcı olarak bikarbonat, ve kalsiyum kaynağı olarak kalsiyum karbonat olan, fiziksel olarak açık dentin tübüllerini tıkayarak ve örterek DAH'nin giderilmesinde etkili olan, Pro-arjin olarak adlandırılan yeni bir teknoloji geliştirilmiştir. ${ }^{73}$ Pro-arjin yumuşak dokuyla uyumludur ve ağrı yaratmaz. Düşük devirde çalışan ve yavaş dönen periodontal lastikle veya pamuk uçlu aplikatörlerle özellikle mine-sement birleşimi olmak üzere açık dentin yüzeylerine uygulanır.

Mikroskopik çalışmalar, pro-arjinin dentin tübüllerini tıkamadaki etkinliğini ve asitlere karşı dirençli bir yapı oluşturduğunu göstermiştir. ${ }^{74,75}$ Histolojik çalışmalar, tübülleri tıkadığını doğrulamış, tıkayıcı mineralin $\mathrm{Ca}^{++}, \mathrm{PO}_{4}$ ve karbonat içerdiğini göstermiştir. Hidrolik iletkenlik deneyleri de bu tıkamanın sıvı akışını önleyerek hidrodinamik mekanizmayı engellediğini göstermiştir. ${ }^{74,75}$ Arjinin ile ilgili uzun süreli takibin yapıldığı çalışmaların yeterli sayıda olmadığı ve çalışmalardaki örnek sayılarının da az olduğu, örnek dağılımı, takip süreci ve örnek sayısı açısından daha yeterli çalışmaların yapılması gerekliliği bildirilmiştir. $^{76}$

Biyoaktif Cam: Biyoaktif cam (Novamin) DAH'nin tedavisinde ve mine remineralizasyonunu sağlamak için kliniğe yönelik dental ürünlerde ve diş macunu formunda (Bioglass, Nupro, Sensodyne Repair\&Protect) üretilmiştir. ${ }^{65}$ Biyoaktif camlar pahalı olmayan ve üretimi kolay ürünlerdir. Fizyolojik sıvilarda kendiliğinden diş yüzeyinde karbonatlı apatit oluşturmaktadır. Biyoaktif camlar dentin tübüllerini tıkayarak etki gösterirler daha da önemlisi tübül içerisinde ve tübül boyunca tübülün mineralizasyonunu indükler ve böylece sıvı akışına karşı kalııı tıkama sağlar. ${ }^{70}$

Adezivler ve Restoratif Materyaller: Adezivler, mekanik ve kimyasal etkenlerle dişten uzaklaşana kadar dentin tübüllerini örterek hassasiyeti giderebilirler. Bu amaçla kullanılan adezivlere örnek olarak, Fuji Bond LC, All-Bond 2, All-Bond SE, Single Bond, Prime Bond NT, Adper Singlebond vb. gösterilebilir. Adeziv sistemlerin dentine bağlanma mekanizmaları esasen kollajen liflerinden ve monomerden oluşan hibrit tabakasını oluşturmadaki başarıya bağlıdır. Bunu etkileyen değişik etkenlerden biri de dentin bağlayıcı sistemlerin içerdikleri solvent tipidir. ${ }^{50}$ Günümüzde dentin bağlayıcı ajanlar su, aseton ve etanol olmak üzere 3 farklı solvent içerirler. Bu solventler, kollajen lifleri arasındaki su ile yer değiştirirler. Bu suyun büyük bir kısmı buharlaşarak uzaklaşır ve böylece kollajen ağı içerisindeki monomer konsantrasyonu artar. Bu da kalan suyun buharlaşma kapasitesini azaltarak bir miktar suyun monomer ile kollajen liflerinin oluşturduğu ağ içerisinde kalmasına neden olur. Etanol, asetona çok benzer ancak; monomeri çözme kapasitesi daha azdır ve asetona göre suyu buharlaştırma basıncı daha düşüktür. Dentin bağlayıcı ajanların içerisinde yüksek buhar basınçlı solventlerin bulunması artık suyun buharlaşmasını kolaylaştırmaktadır. Su da penetrasyon ve nemlendirme özelliğinin iyi olması nedeniyle kollajen lifleri arasına monomerin taşınması amacıyla kullanılabilecek uygun bir solventtir.

Dişte madde kaybı çok fazla ise ve restore edilmesi gerekli ise, rezinler, cam iyonomer simanlar, rezin modifiye cam iyonomerler/kompomerler, ormoserler vb. nano dolduruculu materyallerin uygulanması ile hem doku kaybı giderilir hem de yapılarında kııı görülmediği sürece kabul edilebilir dayanıklılıta dentin tübüllerini tıkayarak DAH'nin önüne geçilebilir.

Ormoserler (Admira Protect, Nano $P$ ve Seal\&Protect) inorganik silan dolduruculara ek olarak inorganik ve organik kopolimer içeren restoratif materyallerdir. Buna ek olarak aseton, HEMA, BISGMA ve flor salınımı yapan üretan dimetakrilat içerir. $\mathrm{Bu}$ içeriğiyle dentin tübüllerini tıkayarak DAH'ni gidermektedir. ${ }^{62}$ Hafif nemli yüzeye uygulandıktan sonra 10 sn ışık uygulanır. Nano P (FGM Dental, Joinville, SC, Brezilya), nanoyapısında $\mathrm{Ca}^{++}$ve $\mathrm{PO}_{4}$ içerir. Bu partiküllerin boyutlarının küçük olması yüzey alanını ve biyolojik aktivitesini arttıır. $\mathrm{Ca}^{++}, \mathrm{PO}_{4}$ ve $\mathrm{F}^{+}$ açık dentin tübüllerini tıkarken $\mathrm{KNO}_{3}$ sinirin uyarılabilirliğini azaltarak DAH'nin tedavisinde çift yönlü etki göstermektedir. Seal \& Protect (Dentsply Detrey $\mathrm{GmbH}$, Konstanz, Almanya) içerdiği amino florür ve triclosan sayesinde hem demineralizasyona karşı dişi korur hem de florür aracilığıyla DAH'ni gidermektedir. ${ }^{62}$

Periodontal Cerrahi: Mukogingival cerrahi yöntemleri; açığa çıkmış dentin bölgelerini en aza indirecek şekilde kök yüzeyinin kapatılmasını hedefler. Özellikle DAH'ne yönelik diğer tüm uygulamalar yetersiz kaldığında ve estetik kaygılar da devreye girdiği zaman denenen bir yöntemdir. DAH açısından sonuçların öngörülebilirliği yeterli değildir ve etkinlikleri sınırı olabilir. Kök yüzeylerinin kapatıması amacıyla serbest diş eti grefti, laterale ya da koronale pozisyone flep, semilunar flep, subepitelyal bağ 
dokusu grefti ve yönlendirilmiş doku rejenarasyonu gibi yöntemler kullanılmaktadır. Yine de araştırmacılar uygulamaların öngörülebilirliğinin sorgulanabileceğini ve buna yönelik daha fazla klinik çalışma yapılması gerektiğini önermişlerdir. ${ }^{77}$

Lazerler: DAH'de kullanılan farklı özellikteki lazerlerin etki mekanizmaları da farklıdır (Tablo 5). ${ }^{60,78,79}$ DAH tedavisinde placebo ile anlamlı bir fark ortaya koyamayan Er;Cr:YSGG lazer haricinde tüm lazerlerin etkili olduğu bildirilmiş ancak

Tablo 5. DAH'de kullanılan lazerler ve etki mekanizmaları ile ilgili düşünceler.

\begin{tabular}{|c|c|c|c|}
\hline $\begin{array}{l}\text { Lazerin } \\
\text { türü }\end{array}$ & $\begin{array}{l}\text { Gücü, } \\
\text { Dalga } \\
\text { Boyu }\end{array}$ & $\begin{array}{l}\text { tkinlik } \\
\text { Püzdesi }\end{array}$ & Etki Mekanizması \\
\hline$\underset{60,78}{\text { He-Ne lazer }}$ & $\begin{array}{l}\text { Düşük } \\
\text { güçte } \\
(6 \mathrm{~mW}, 5 \\
\mathrm{Hz})\end{array}$ & $\begin{array}{l}\% 5,2- \\
\% 100\end{array}$ & $\begin{array}{l}\text { *Sinirlerin elektriksel } \\
\text { aktivitelerini ( } \mathrm{A} \delta \text { ve C sinir } \\
\text { liflerinin aksiyon potansiyelini) } \\
\text { değiştirmekte } \\
\text { *Dentin yüzeyinde morfolojik } \\
\text { değişiklik yok }\end{array}$ \\
\hline $\begin{array}{c}\text { Diyot } \\
\text { lazer }\end{array}$ & $\begin{array}{l}\text { Düşük } \\
\text { güçte } \\
\text { ( } 20-60 \mathrm{~mW}) \\
\text { (780,830,90 } \\
0 \mathrm{~nm} \text { dalga } \\
\text { boyu) }\end{array}$ & $\begin{array}{l}\% 30- \\
\% 100\end{array}$ & $\begin{array}{l}\text { *C sinir liflerinin } \\
\text { depolarizasyonunu engelleyerek } \\
\text { analjezik etki oluşturmakta } \\
\text { *Odontoblast stimulasyonu, } \\
\text { irregular tamir dentini üretimi } \\
\text { ile dentin tübüllerinin tıkanması } \\
\text { *Dentin yüzeyinde morfolojik } \\
\text { değişiklik yok }\end{array}$ \\
\hline $\begin{array}{c}\text { Nd:YAG } \\
\text { lazer } 60,78,79\end{array}$ & $\begin{array}{l}\text { Orta güçte } \\
(1-2 \\
\text { W,1064 nm } \\
\text { dalga boyu) }\end{array}$ & $\begin{array}{l}\% 5,2- \\
\% 100\end{array}$ & $\begin{array}{l}\text { *C ve Aठ sinir liflerinin direkt } \\
\text { analjezisi } \\
\text { *Dentin tübüllerinin daraltılıp } \\
\text { tıkanması } \\
\text { *Na pompası mekanizmasını } \\
\text { engelleyerek permeabilitenin } \\
\text { değişmesi } \\
\text { *1.5 W> dentinde erime, } 1.5 \\
\text { W< kökte çatlak ve fissürler, } \\
\text { pulpada yaralanma }\end{array}$ \\
\hline$\underset{60,78}{\mathrm{CO}_{2} \text { lazer }}$ & $\begin{array}{l}\text { Orta güctte } \\
(0,5-1 \mathrm{~W})\end{array}$ & $\begin{array}{l}\text { \%59, } \\
8- \\
\% 100\end{array}$ & $\begin{array}{l}\text { *Dentinin erimesi ile kanalların } \\
\text { daralması ve tıkanması } \\
\text { *Dentinde permeabilitenin } \\
\text { azalması } \\
\text { *Dentinde kuruma }\end{array}$ \\
\hline $\begin{array}{c}\text { Er:YAG } \\
\text { lazer }{ }^{54,60}\end{array}$ & $\begin{array}{l}\text { Orta güçte } \\
\text { ( } 80 \\
\text { mJ/atım, } 3 \\
\mathrm{~Hz}, 2940 \\
\mathrm{~nm} \text { ) }\end{array}$ & & $\begin{array}{l}\text { *Suda yoğun absorbsiyonu ile } \\
\text { lazer irradiyasyonu sonucu } \\
\text { dentin lenfinin buharlaşmasıyla } \\
\text { ekspoze dentin kanallarının } \\
\text { içerisinde çözünmez tuzların } \\
\text { depozisyonu sonucu dentin } \\
\text { kanallarını tıkama } \\
\text { *Yüksek bakterisidal potansiyel } \\
\text { ile ağrı eşiğini düşüren } \\
\text { inflamatuar mediyatörlerin } \\
\text { salınımını azaltarak dentin } \\
\text { hassasiyetini azaltmakta } \\
\text { *Termal olarak güvenli } \\
\end{array}$ \\
\hline $\begin{array}{c}\text { Er;Cr:YAG } \\
\text { lazer }^{60}\end{array}$ & $\begin{array}{l}\text { Orta güçte } \\
(2780 \mathrm{~nm})\end{array}$ & & $\begin{array}{l}\text { *Er:YAG lazer ile benzer etki } \\
\text { mekanizması } \\
\text { *Termal olarak güvenli }\end{array}$ \\
\hline
\end{tabular}

Er;Cr:YSGG lazer çalışmalarının azlığının bu yargının güvenilirliğini azalttığı belirtilmiştir. ${ }^{80} \mathrm{Nd}$ :YAG lazer ışınlarının emilimini arttıran ve ışınların daha iç bölgelere penetrasyonunu önleyerek pulpanın korunmasını sağlayan siyah mürekkep kullanılmasını öneren ve etkinliğin arttığını bildiren çalışmalar vardır. ${ }^{81}$

Diğer Tedavi Yöntemleri: DAH tedavisinde kullanılan $\mathrm{Ca}(\mathrm{OH})_{2}{ }^{\prime}$ in $\mathrm{DAH}$ üzerindeki etkisini $\mathrm{Ca}^{++}$ iyonlarınının protein yapılarını değiştirerek ve açı̆̆a çıkmış dentin üzerinde bağlantı tabakası oluşturarak gerçekleştirdiği öne sürülmüştür. Hızlı etkisine rağmen çoklu uygulama gerektirdiği ve gingival iritasyona neden olduğu da bildirilmiştir. ${ }^{82}$

Proteini çökelterek etki eden gümüş nitrat, formaldehit ve çinko klorür geçmişte oldukça yaygın kullanılan ancak dişlerde kalıcı renklenmeye neden olduklarından ve dişeti ile pulpaya zararlı olduklarından günümüzde kullanılmayan maddelerdir. ${ }^{70}$

Tükürükteki $\mathrm{Ca}^{++}$ve $\mathrm{PO}_{4}$ iyonlarının azlığı nedeniyle verniklere bu iyonların eklenmesi ve böylelikle flor aracılı remineralizasyonun teşvik edilmesi fikri ortaya çıkmıştır. Bu amaçla kalsiyum ve fosfatın etkileşime girmeden 2 fazlı salınım yoluyla kullanıldığı amorf kalsiyum fosfat (ACP) geliştirilmiştir. $^{70}$ Enamel-Pro (Premier Dental, Plymouth Meeting, PA, ABD) verniğin, içeriğindeki ACP sayesinde hidrolik iletimi \%73 oranında azalttığı bildirilmektedir. İçeriğindeki florürle birlikte ACP florapatit oluşturarak dentin tübüllerini tıkadığı ve sadece flor içeren verniklere oranla 4 kat fazla florür sağladığı gösterilmiştir. Su bazlı ve 900 ppm flor içeren CPP-ACP pat formundaki GC MI Paste Plus, topikal olarak uygulanabildiği gibi diş macunu şeklinde de kullanılmaktadır.

Antiinflamatuar ajanlardan kortikosteroidlerin DAH tedavisinde kullanılması önerilmiş, tam olarak etkinliği kanıtlanamasa da dentin tübüllerinin tıkanmasında mineralizasyonu arttırarak hassasiyeti azaltacakları düşünülmüştür. ${ }^{82}$

Son olarak bir çalışmada DAH tedavisinde propolis (arıların kovanlarını dezenfekte etmek ve yalıtmak amacıyla ürettikleri bir kimyasal) kullanılmıştır. ${ }^{83}$ Bu çalışmada bir gruba APF diğer gruba ise propolis uygulanmış ve çalışma sonunda iki ajanın etkinliğinde fark bulunamamıştır. 


\section{SONUÇ}

Dentin aşırı hassasiyeti (DAH), açığa çıkmış dentinin, termal, buharlaşma, dokunma, elektriksel, osmotik veya kimyasal uyaranlara karşı oluşturduğu ve başka hiçbir dental patoloji, defekt ve hastalık olarak tanısı konulamayan, tipik, kısa süreli, şiddetli, keskin ağrı ile karakterize durumudur. DAH'nin oluşturduğu ağrı mekanizması halen kesin olarak anlaşılamamıştır. Görülme sıklığı gün geçtikçe artan DAH diğer tüm patolojilerin elenmesi ile teşhis edilebildiği için teşhisi zor bir durumdur. Tedavisi amacıyla pek çok materyal ve yöntem denenmiştir ancak henüz altın standart olabilecek bir yöntem belirlenememiştir. Bu yüzden DAH'nin ağrı mekanizmasını kesin olarak anlamak ve tedavisinde daha uzun süreli ve daha etkili yöntemleri belirlemek amacıyla çalışmalar yapılmaya devam edilmelidir. Özellikle tedavi yöntemleri ile ilgili uzun süreli takibi yapılan klinik çalışmalara intiyaç vardır.

\section{KAYNAKLAR}

1. Gernhardt CR. How valid and applicable are current diagnostic criteria and assesment methods for dentin hypersensitivity? An overview. Clin Oral Invest 2013;17:31-40.

2. Attar N, Korkmaz Y. Dentin aşırı hassasiyeti. Hacettepe Üniv Diş Hek Fak Derg 2006;30:83-91

3. Bamise CT, Olusile AO, Oginni AO, Dosumu OO. The prevalence of dentine hypersensitivity among adult patients attending a Nigerian teaching. Oral Health Prev Dent 2007;5:49-53.

4. Chabanski MB, Gillam DG, Bulman JS, Newman HN. Clinical evaluation of cervical dentine sensitivity in a population of patients referred to a specialist periodontology department: a pilot study. J Oral Rehabil 1997;24:666-72.

5. West XN, Sanz M, Lussi A, Bartlett D, Bouchard P, Bourgeois $D$. Prevelance of dentine hypersensitivity and study of associated factors: A European population-based cross-sectional study. J Dent 2013;41:841-51.

6. Ye W, Feng X-P, Li R. The prevalence of dentine hypersensitivity in Chinese adults. J Oral Rehabil 2012;39:182-7.

7. Gillam DG, Newman HN. Assessment of pain in cervical dentinal sensitivity studies. J Clin Periodontol1993;20:383-94.
8. Gernhardt CR. How valid and applicable are current diagnostic criteria and assesment methods for dentin hypersensitivity? An overview. Clin Oral İnvest 2013;17:31-40.

9. Ernst E. Placebo: new insights into an old enigma. Drug Discov Today 2007;12:413-8.

10. McCarney R,Warner J, IIiffe S, van Haselen R, Griffin M, Fisher P. The Hawthorne Effect: a randomised, controlled trial. BMC Med Res Methodol 2007;7:30.

11. Markowitz K. A new treatment alternative for sensitive teeth: A desensitizing oral rinse. J Dent 2013;41:1-11.

12. Barsky AJ, Saintfort R, Rogers MP, Borus JF. Nonspecific medication side effects and the nocebo phenomenon. JAMA 2002;287:622-7.

13. West NX, Lussi A, Seong J, Hellwig E. Dentin hypersensitivity: pain mechanisms and aetiology of exposed cervical dentin. Clin Oral Invest 2013;17:9-19.

14. Dellow PG, Roberts ML. Bradykinin application to dentine: A study of a sensory receptor mechanism. Aust Dent J 1966;11:384-7

15. Pashley DH. Smear layer physiological considerations. Oper Dent 1984;3:13-29.

16. Rugg-Gunn AJ, Macgregor IDM. A survey of toothbrushing behaviour in children and young adults. J Periodontal Res 1978;13:382-9.

17. Haywood VB. Dentine Hypersensitivity: bleaching and restorative considerations for successfull management. Int Dent J 2002;52:7-10.

18. Orbak R. Dentin Aşırı Duyarlılığı. Atatürk Üniv. Diş Hek. Fak. Derg. 1995;5:104-11.

19. Schiff T, Dotson M, Cohen S, De Vizio W, McCool J, Volpe A. Efficacy of a dentifrice containing potassium nitrate, soluble pyrophosphate, PVM/MA copolymer, and sodium fluoride on dentinal hypersensitivity: a twelve-week clinical study.J Clin Dent 1994;5:87-92.

20. Pereira R, Chava VK. Efficacy of a $3 \%$ potassium nitrate desensitizing mouthwash in the treatment of dentinal hypersensitivity. J Periodontol 2001; 72: 1720-5.

21. Pradeep AR, Agarwal E, Naik SB, Bajaj P, Kalra N. Comparison of efficacy of three commercially available dentifrices on dentinal hypersensitivity: a randomized clinical trial. Aust Dent J 2012;57:42934. 
22. Wara-aswapati N, Krongnawakul D, Jiraviboon D, Adulyanon S, Karimbux N, Pitiphat W. The effect of a new toothpaste containing potassium nitrate and triclosan on gingival health, plaque formation and dentin hypersensitivity. J Clin Periodontol 2005; 32:53-8.

23. Guentsch A, Seidler K, Nietzsche S, Hefti AF, Preshaw PM, Watts DC, Klaus DJ, Bernd WS. Biomimetic mineralization: Long-term observations in patients with dentin sensitivity. Dent Mater 2012; 27: 457-64.

24. Minkoff S, Axelrod S. Efficacy of Strontium Chloride in Dental Hypersensitivity, J Periodontol 1987; 58: 470-4.

25. Hughes $N$, Mason S, Jeffery $P$, Welton $H$, Tobin $M$, O'Shea C, Browne M. A comparative clinical study investigating the efficacy of a test dentifrice containing 8\% strontium acetate and 1040 ppm sodium fluoride versus a marketed control dentifrice containing $8 \%$ arginine, calcium carbonate, and $1450 \mathrm{ppm}$ sodium monofluorophosphate in reducing dentinal hypersensitivity. J Clin Dent 2010; 21:49-55.

26. Mason S, Hughes N, Sufi F, Bannon L, Maggio B, North $M$, Holt J. A comparative clinical study investigating the efficacy of a dentifrice containing 8\% strontium acetate and $1040 \mathrm{ppm}$ fluoride in a silica base and a control dentifrice containing 1450 ppm fluoride in a silica base to provide immediate relief of dentin hypersensitivity. J Clin Dent 2010;21:42-8.

27. Parkinson $C R$, Willson RJ. An in vitro investigation of two currently marketed dentin tubule occlusion dentifrices. J Clin Dent 2011;22:6-10.

28. Ni LX, He T, Chang A, Sun L. The desensitizing efficacy of a novel stannous-containing sodium fluoride dentifrice: an 8-week randomized and controlled clinical trial. Am J Dent 2010;23:17B21B.

29. Schiff T, Bonta Y, Proskin HM, DeVizio W, Petrone $M$, Volpe AR. Desensitizing efficacy of a new dentifrice containing $5.0 \%$ potassium nitrate and $0.454 \%$ stannous fluoride. Am J Dent 2000;13:111-5.

30. Aparna S, Setty S, Thakur S. Comparative efficacy of two treatment modalities for dentinal hypersensitivity: A clinical trial. Indian J Dent Res 2010; 21:544-8.
31. Kern DA, McQuade MJ, Scheidt MJ, Hanson B Dyke TEV. Effectiveness of Sodium fluoride on tooth hypersensitivity with and without Iontophoresis. J Periodontol 1989;60:387-9.

32. Singal P, Gupta R, Pandit N. 2\% Sodium fluorideiontophoresis compared to a commercially available desensitizing agent. J Periodontol 2005;76:351-7.

33. Gillam DG, Mordan NJ, Sinodinou AD, Tang JY Knowles JC. The effects of oxalate-containing products on the exposed dentine surface: an SEM investigation. J Oral Rehabil 2001;28:1037-44.

34. Yiu CKY, King NM, Suh BI, Sharp L, Carvalho RM, Pashley DH, Tay FR. Incompatibility of oxalate desensitizers with acidic, fluoride-containing totaletch adhesives . J Dent Res 2005;84:730-5.

35. Vachiramon V, Vargas MA, Pashley DH, Tay FR, Geraldeli S, Qian F, Armstrong SR. Effects of oxalate on dentin bond after 3-month simulated pulpal pressure. J Dent 2008;36:178-85.

36. Lehmann N, Degrange $M$. Effect of four dentin desensitizer on the shear bond strength of three bonding systems. Eur Cell Mater 2005;9:52-3.

37. Huh JB, Kim J-H, Chung M-K, Lee H-Y,Choi Y-G, Shim J-S. The effect of several dentin desensitizers on shear bond strength of adhesive resin luting cement using self-etching primer. J Dent 2008;36:1025 -32.

38. Hamlin D, Williams KP, Delgado E, Zhang YP, Devizio W, Mateo LR. Clinical evaluation of the efficacy of a desensitizing paste containing $8 \%$ arginine and calcium carbonate for the in-office relief of dentin hypersensitivity associated with dental prophylaxis. Am J Dent 2009;22:16A-20A

39. Schiff T, Delgado E, Zhang YP, Cummins D, Devizio W, Matio LR. Clinical evaluation of the efficacy of an in-office desensitizing paste containing $8 \%$ arginine and calcium carbonate in providing instant and lasting relief of dentin hypersensitivity. Am J Dent 2009;22:8A-15A.

40. Boneta ARE, Ramirez K, Naboa J, Mateo LR, Stewart B, Panagokos F, De Vizio W. Efficacy in reducing dentine hypersensitivity of a regimen using a toothpaste containing $8 \%$ arginine and calcium carbonate, a moutwash containing $0.8 \%$ arginine, pyrophosphate and PVM/MA copolymer and a toothbrush compared to potassium and negative control regimens: An eight-week 
randomized clinical trial. J Dent 2013;41:42-9.

41. Boneta ARE, Salas RMG, Mateo LR, Stewart B, Mello S, Arvanitidou LS, Panagokos F, De Vizio W. Efficacy of a mouthwash containing $0.8 \%$ arginine, PVM/MA copolymer, pyrophosphates, and $0.05 \%$ sodium fluoride compared to a commercial mouthwash containing $2.4 \%$ potassium nitrate and $0.022 \%$ sodium fluoride and a control mouthwash containing $0.05 \%$ sodium fluoride on dentine hypersensitivity: A six-week randomized clinical study. J Dent 2013;415:34- 41.

42. Mitchell JC, Musanje L, Ferracane JL. Biomimetic dentin desensitizer based on nano-structured bioactive glass. Dent Mater 2011;27:386-93.

43. Lynch E, Brauer DS, Karpukhina N, Gillam DG, Hill RG. Multi-component bioactive glasses of varying floride content for treating dentin hypersensitivity. Dent Mater 2012;28:168-78.

44. Chen WC \& CS, Kung JC, Hsiao YC, Shih CJ, Chien CS. Effects of bioactive glass with and without mesoporous structures on desensitization in dentinal tubule occlusion. App Sur Sci 2013; 283: 833-42.

45. Tirapelli C, Panzeri H, Lara EHG, Soares RG, Peitl $\mathrm{O}$, Zanotto ED. The effect of a novel crystallised bioactive glass ceramic powder on dentin hypersensitivity a long term clinical study. J Oral Rehabil 2011;38:253-62.

46. Ananthakrishna S, Raghu TN, Koshy S, Kumar N. Clinical evaluation of the efficacy of bioactive glass and strontium chloride for treatment of dentinal hypersensitivity. J Interdiscip Dentistry 2012;2:927.

47. Bakry AS, Tamuro Y, Otsuki M, Kasugai S, Ohya K, Tagami J. Ctotoxicity of 4555 bioglass paste used for dentine hypersensitivity treatment. J Dent 2011;39:599-603.

48. Forsback A. \& P, Areva S, Salonen JI. Mineralization of dentin induced by treatment with bioactive glass S53P4 in vitro. Acta Odontol Scand 2004; 62:14-20.

49. Polderman RN, Frencken JE. Comparison between effectiveness of a low-viscosity glass ionomer and a resin-based glutaraldehyde containing primer in treating dentine hypersensitivity-a 25.2-month evaluation . J Dent 2007;35:144-9.

50. Ünlü İ, Bala O. Dentin duyarlılığı tedavisinde değişik materyallerin etkinliğinin klinik olarak değerlendirilmesi. GÜ Diş Hek Fak Derg 2008; 25 : 13-8.

51. Akca $A E$, Gökce $S$, Kürkçü $M$, Özdemir A. Clinical assessment of bond and fluoride in dentin hypersensitivity. Hacettepe Üniv. Diş Hek Fak Derg 2006; 30:92-100.

52. Yu $X$, Liang $B$, Jin $X$, Fu B, Hanning $M$. Comparative in vivo study on the desensitizing efficacy of dentin desensitizers and one-bottle selfetching adhesives. Oper Dent 2010;35:279-86.

53. Birang R, Poursamimi J, Gutknecht N, Lampert F, Mir $M$. Comparative evaluation of the effects of Nd:YAG and Er:YAG laser in dentin hypersensitivity treatment. Lasers Med Sci 2007;22:21-4.

54. Schwarz F, Arweiler N, Georg T, Reich E. Desensitizing effects of an Er:YAG laser on hypersensitive dentine. A controlled, prospective clinical study. J Clin Periodontol2002;29:211-5.

55. Yılmaz HG, Cengiz $E$, Kurtulmuş-Yılmaz $S$, Leblebicioğlu B. Effectiveness of Er,Cr:YSGG laser on dentine hypersensitivity: a controlled clinical trial. J Clin Periodontol 2011;38:341-6.

56. Yılmaz HG, Kurtulmuş-Yılmaz S, Cengiz E. Clinical evaluation of Er,Cr:YSGG and GaAIAs laser therapy for treating dentine hypersensitivity: A randomized controlled clinical trial. J Dent 2011;39:249-54.

57. Akca AE, Gökce S, Kürkçü M, Özdemir A. A clinical investigation of low level laser irradiation on hypersensitive dentine. Hacettepe Diş Hek Fak Derg 2006;30:92-9.

58. Yılmaz HG, Kurtulmuş-Yılmaz S, Cengiz E. Longterm effect of diode laser irradiation compared to sodium flouride varnish in the treatment of dentine hypersensitivity in peirodontal maintenance patients: A randomized controlled clinical study. Photomed Laser Surg 2011;29:721-5.

59. Lopes AO, Aranha ACC. Comparative evaluation of the effects of $\mathrm{Nd}$ :YAG laser and a desensitizer agent on the treatment of dentin hypersensitivity: A clinical. Photomed Laser Surg 2013;31:132-8.

60. Yılmaz HG, Bayındır H, Cengiz E, Berberoğlu A. Dentin hassasiyeti ve tedavi yöntemleri. Cumhuriyet Dent J 2012;15:71-82.

61. Orchardson R, Gillam DG. The efficacy of potassium salts as agents for treating dentin hypersensitivity. J Orofac Pain 2000;14:9-19.

62. Bozok Y. Dentin hassasiyeti tedavisinde diş hekimi tarafından uygulanan desensitize edici ajanlar. 
ADO Klinik Bilimler Dergisi 2011;5:867-74.

63. Schüpbach $P$, Lutz F, Finger WJ. Closing of dentinal tubules by Gluma desensitizer. Eur J Oral Sci 1997;105:414-21.

64. Jain P, Vargas MA, Denehy GE, Boyer DB. Dentin desensitizing agents: SEM and $X$-ray microanalysis assessment. Am J Dent 1997;10:21-6.

65. Shiau HJ. Dentin hypersensitivity. J Evid Base Dent Pract 2012;12:220-8.

66. Banfield N, Addy $M$. Dentine hypersensitivity: development and evaluation of a model in situ to study tubule patency. J Clin Periodontol 2004;31:325-35.

67. Pinto SCS, Silveria CMM, Pochapski MT, Pilatti GL, Santos FA. Effect of desensitizing toothpastes on dentin. Braz Oral Res 2012;26:410-7.

68. Rölla G, Saxeguard E. Critical evaluation of the composition and use of topical fluorides, with emphasis on the role of calcium fluoride in caries inhibition. J Dent Res 1990;69:780-5.

69. Ripa LW. A critique of topical fluoride methods (dentifrices, mouthrinses, operator-, and selfapplied gels) in an era of decreased caries and increased fluorosis prevalence. J Public Health Dent 1991;51:23-41.

70. Bozok Y. Dentin hassasiyeti, etiyolojisi ve tedavisinde güncel yaklaşımlar: Hassasiyet giderici diş macunları. ADO Klinik Bilimler Dergisi 2011;5:859-66.

71. Cunha-Cruz J, Stout JR, Heaton U, Wataha JC. Dentin hypersensitivity and oxalates: a systematic review. J Dent Res 2011;90:304-3

72. Sezgin B, Tarım B. Dentin hassasiyeti ve tedavisi. İstanbul Üniversitesi Diş Hekimliği Fakültesi Dergisi 2012;46:88-100.

73. Panagakos F, Schiff T, Guignon A. Dentin hypersensitivity: Effective treatment with an inoffice desensitizing paste containing $8 \%$ arginine and calcium carbonate. Am J Dent 2009;22:3A-7A.

74. Cummins D. Dentin hypersensitivity: from diagnosis to a breakthrough therapy for everyday sensitivity relief. J Clin Dent 2009;20:1-9.

75. Petrou I, Heu R, Stranick M, Lavender S, Zaidel L, Cummins D, Sullivan RJ, Hsueh C, Gimzewski JK. A breakthrough therapy for dentin hypersensitivity: how dental products containing $8 \%$ arginine and calcium carbonate work to deliver effective relief of sensitive teeth. J Clin Dent 2009; 20: 23-31.
76. Sharif MO, Iram S, Brunton PA. Effectiveness of arginine containing toothpastes in treating dentin hypersensitivity: A systematic review. J Dent 2013; 41:483-92.

77. Oliveira DWD, Oliveira-Ferreira F, Flecha OD, Gonçalves PF. Is surgical root coverage effective for the treatment of cervical dentin hypersensitivity? A systematic review. J Periodontol 2013;84: 295-306.

78. Kimura Y, Wilder-Smith P, Yonaga K, Matsumoto K. Treatment of dentine hypersensitivity by lasers: $a$ review. J Clin Periodontol 2000;27:715-21.

79. Myers TD, McDaniel JD. The pulsed Nd:YAG dental laser: review of clinical applications. J Can Dent Assoc 1991;19:25-30.

80. Sgolastra F, Petrucci A, Severino M, Gatto R, Monaco A. Lasers for treatment of dentin hypersensitivity: A meta-analysis. J Dent Res 2013;92:492-9.

81. Yonaga K, Kimura Y, Matsumoto K. Treatment of cervical dentin hypersensitivity by various methods using pulsed Nd:YAG laser. J Clin Laser Med Surg 1999;17:205-10.

82. Yılmaz D, Güncü GN. Dentin hassasiyeti: mekanizmalar, etiyoloji ve tedavi yaklaşımları. ADO Klinik Bilimler Dergisi 2011;5:833-40.

83. Toker H, Özan F, Özdemir H, Değer O. Dentin hassasiyetinin tedavisinde propolisin etkisi. GÜ Diş Hek Fak Derg 2008;25:1-6.

\author{
Yazışma Adresi \\ Dt. İzgen Hacıŏulları \\ Yakın Doğu Üniversitesi \\ Diş Hekimliği Fakültesi \\ Restoratif Diş Tedavisi Anabilim Dalı \\ Lefkoşa-K.K.T.C., \\ Tel: 05428720987/05338689466, \\ Faks: 03926802025, \\ e-posta: izgen96h@gmail.com,
}

